\title{
PENERAPAN METODE SAS (STRUKTURAL ANALITIK SINTETIK) UNTUK MENINGKATKAN KETERAMPILAN MEMBACA SISWA KELAS RENDAH
}

\author{
Hery Wardiyati \\ wardiyati.hery68@gmail.com \\ SD Negeri 016 Marsawa
}

\begin{abstract}
Reading is an activity to get meaning or information from a reading. Therefore, reading is a very important thing to learn. But based on the observations of researchers at 016 Marsawa State Elementary School, researchers still found students whose reading abilities were lacking. The purpose of this study is to improve students' reading skills by applying synthetic analytic structural methods (SAS). This study uses classroom action research consisting of two cycles. each cycle consists of 1) planning, 3) implementation, 4) observation, and 5) reflection. The results showed, on the base score, 13 students completed with a percentage of $46.4 \%$ while students who did not complete as many as 15 with a percentage of $53.6 \%$ with the category of incomplete. In the first cycle, students who completed completed increased to 21 with a percentage of $75 \%$, while students who did not complete as many as 7 people with a percentage of $25 \%$ with a complete category. In the second cycle, students who completed again increased to 25 with a percentage of $89.2 \%$, while those who did not complete reduced to 3 people with a percentage of $10.8 \%$ complete category. Viewed from the results of students' reading skills; the basic score with an average of 60.07 then increased with an average number of 72.80 in cycle I. In cycle II an increase occurred with an average of 87.25. The increase in reading skills in the basic score to the first cycle was $12.73 \%$ while the increase in reading skills of students in the first cycle to the second cycle was $14.45 \%$. From these results it can be concluded that the application of structural analytic synthetic (SAS) methods can improve the reading skills of low grade students in primary schools.
\end{abstract}

Keywords: structural synthetic analytic (SAS), reading skills

\begin{abstract}
ABSTRAK
Membaca merupakan aktivitas mendapatkan makna atau informasi dari suatu bacaan. Oleh karena itu, membaca merupakan suatu hal yang sangat penting untuk dipelajari. Namun berdasar observasi peneliti di SD Negeri 016 Marsawa, peneliti masih menemukan siswa yang kemampuan membacanya kurang. Adapun tujuan dari penelitian ini adalah untuk meningkatkan keterampilan membaca siswa dengan penerapan metode struktural analitik sintetik (SAS). Penelitian ini menggunakan penelitian tindakan kelas yang terdiri dari dua siklus. setiap siklus terdiri dari 1) perencanaan, 3) pelaksanaan, 4) pengamatan, dan 5) refleksi. Hasil penelitian menunjukan, pada skor dasar, siswa yang tuntas sebanyak 13 dengan persentase $46.4 \%$ sedangkan siswa yang tidak tuntas sebanyak 15 dengan persentase $53.6 \%$ dengan kategori tidak tuntas. Pada siklus I, siswa yang tuntas meningkat menjadi 21 dengan persentase $75 \%$, sedangkan siswa yang tidak tuntas sebanyak 7 orang dengan persentase $25 \%$ dengan kategori tuntas. Pada siklus II, siswa yang tuntas kembali meningkat menjadi 25 dengan persentase $89.2 \%$, sedangkan yang tidak tuntas berkurang menjadi 3 orang dengan persentase $10.8 \%$ kategori tuntas. Dilihat dari hasil keterampilan membaca siswa; pada skor dasar dengan rata-rata 60,07 kemudian mengalami peningkatan yaitu dengan jumlah rata-rata 72.80 pada siklus I. Pada siklus II terjadi lagi peningkatan dengan rata-rata 87.25 . Peningkatan keterampilan membaca pada skor dasar ke siklus I sebesar $12.73 \%$ sedangkan peningkatan keterampilan membaca siswa pada siklus I ke siklus II sebesar $14.45 \%$. dari hasil ini dapat disimpulkan bahwa penerapan metode struktural analitik sintetik (SAS) dapat meningkatkan keterampilan membaca siswa kelas rendah di sekolah dasar.
\end{abstract}

Kata Kunci: struktural analitik sintetik (SAS), keterampilan membaca

\begin{tabular}{|c|c|c|}
\hline Submitted & Accepted & Published \\
\hline 11 Agustus 2019 & 14 September 2019 & 21 September 2019 \\
\hline
\end{tabular}

\begin{tabular}{|l|c|c|c|c|}
\hline Citation & $:$ & $\begin{array}{l}\text { Wardiyati, H. (2019). Penerapan Metode SAS (Struktural Analitik Sintetik) Untuk Meningkatkan Keterampilan Membaca } \\
\end{array}$ & $\begin{array}{l}\text { Siswa Kelas Rendah. Jurnal PAJAR (Pendidikan dan Pengajaran), 3(5), 1083-1091. DOI: } \\
\text { http://dx.doi.org/10.33578/pjr.v3i5.7837. }\end{array}$ & \\
\hline
\end{tabular}

*Copyright $\odot 2019$ Jurnal PAJAR (Pendidikan dan Pengajaran)

Publish by PGSD FKIP Universitas Riau, Pekanbaru, Indonesia

\section{PENDAHULUAN}

Pembelajaran bahasa Indonesia memiliki empat komponen keterampilan berbahasa. Menurut Tarigan (2008) komponen keterampilan berbahasa tersebut seperti menyimak, berbicara, membaca, dan menulis. Dari empat komponen tersebut keterampilan membaca di sekolah dasar (SD) memegang peranan penting dalam mengembangkan kemampuan berbahasa siswa, 
karena membaca dapat memperluas pengetahuan, wawasan, dan kemampuan siswa. Dengan membaca siswa akan membentuk kemampuan berfikir lewat proses menangkap gagasan atau informasi, memahami, mengimajinasikan, dan menerapkannya. Keterampilan membaca perlu diterapkan saat anak masih sedini mungkin karena membaca merupakan dasar utama yang harus dimiliki siswa.

Membaca merupakan suatu proses yang dimaksudkan informasi dari teks dan pengetahuan yang dimiliki oleh pembaca mempunyai peranan yang utama dalam membentuk makna (Kurniaman, 2016). Menurut Abidin (2012) membaca secara sederhana dikatakan sebagai proses membunyikan lambang bahasa tertulis. Tarigan (2008) membaca adalah proses yang dilakukan serta dipergunakan oleh pembaca untuk memperoleh pemahaman atas isi bacaan yang hendak disampaikan oleh penulis melalui media kata-kata/ bahasa tulis. Lebih lanjut membaca merupakan suatu kegiatan yang berupaya untuk menemukan berbagai informasi yang terdapat dalam tulisan. Hal ini berarti membaca merupakan proses berfikir untuk memahami isi teks yang dibaca. Dalam pengertian ini, membaca sering disebut sebagai membaca nyaring atau membaca permulaan. Membaca juga dapat dikatakan sebagai proses untuk mendapatkan informasi yang terkandung dalam teks bacaan untuk memperoleh pemahaman atas bacaan tersebut.

Pembelajaran membaca di SD dibagi menjadi dua yaitu, (a) membaca permulaan di kelas I, II dan III, (b) membaca lanjut di kelas IV sampai VI. Membaca permulaan menekankan pada pengenalan huruf vocal, konsonan, dan diftong sehingga dilakukan dengan membaca nyaring dan lancar (bersuara). Membaca permulaan merupakan tahap awal dalam belajar membaca yang difokuskan kepada mengenal simbol-simbol atau tanda-tanda yang berkaitan dengan huruf-huruf sehingga menjadi pondasi agar siswa dapat melanjutkan ketahap membaca permulaan (Darwadi dalam Wigati, 2015). Lebih lanjut, membaca permulaan adalah membaca yang diajarkan secara terprogram kepada anak prasekolah. Program ini merupakan perhatian pada kata-kata utuh, bermakna dalam konteks pribadi siswa dan bahan-bahan yang diberikan melalui permainan dan kegiatan yang menarik sebagai perantaran pembelajaran (Susanto, 2011).

Menurut Zuchdi dan Budiasih (dalam Mariyana, 2016), membaca permulaan harus dilakukan secara bertahap, yaitu tahap pramembaca dan membaca. Pada tahap pramembaca anak akan diajarkan sebagai berikut: 1) sikap yang baik pada waktu membaca, seperti sikap duduk yang benar; 2) cara anak meletakkan buku di meja. 3) cara anak memegang buku; 4) cara anak dalam membuka dan membalik-balik buku; dan 5) cara anak melihat dan memperthatikan tulisan.

Pada tahap membaca permulaan, dititik beratkan pada kesesuaian antara tulisan dan bunyi yang ada, kelancaran dan kejelasan suara, pemahaman isi atau makna. Persiapan membaca didukung dengan pengalaman keaksaraan seperti membaca buku atau sering menggunakan tulisan maupun simbol saat pembelajaran. Bahan-bahan untuk membaca permulaan harus sesuai dengan bahasa dan pengalaman anak.

Tujuan membaca permulaan di kelas rendah adalah agar siswa dapat membaca katakata dan kalimat sederhana dengan lancar dan tepat. Kelancaran dan ketepatan anak membaca pada tahap belajar membaca permulaan dipengaruhi oleh keaktifan dan kreativitas guru yang mengajar di kelas rendah. Dengan kata lain, guru memegang peranan yang strategis dalam meningkatkan keterampilan membaca siswa.

Kenyataan di lapangan, khususnya di kelas II SD Negeri 016 Marsawa Kecamatan Sentajo Raya masih terdapat siswa yang kemampuan membacanya kurang. Hal ini dibuktikan oleh hasil belajar siswa dalam kemampuan membaca masih dibawah kriteria ketuntasan minimum (KKM) yang telah ditetapkan sekolah sebesar 70. Dari 28 siswa, yang tuntas hanya 13 siswa dengan persentase $46.4 \%$ dan yang tidak tuntas 15 siswa dengan persentase 53,6\%. Faktor penyebab masih rendahnya hasil keterampilan membaca siswa disebabkan karena kemampuan membaca siswa masih sangat kurang, seperti kefasihan dalam membaca kurang lancar, selain itu, pelafalan dan intonasi dalam membaca belum tepat. Faktor penyebab lain rendahnya kemampuan membaca 
siswa diantaranya minat baca siswa masih sangat kurang. Hal ini dibuktiikan oleh masih banyaknya siswa yang malas membaca baik di sekolah maupun dirumah. Bimbingan dari keluarga dan motivasi yang diberikan kepada siswa baik dari guru maupun keluarga masih kurang, serta teknik pembelajaran yang digunakan guru masih secara konvensional. Sejalan dengan pendapat (Mariyana, 2016) lemahnya keterampilan embaca siswa disebabkan kaena kurangnya kuantitas membaca serta kurangnya ketelitian siswa sewaktu membaca. Lebih lanjut Simanjuta (2017) mengatakan lemahnya keterampilan siswa dalam membaca dipengaruhi oleh cara mengajar guru yang kurang bervariasi.

\section{KAJIAN TEORETIS}

Struktural analitik sintetik atau yang biasa disingkat dengan SAS merupakan salah satu metode yang dapat digunakan dalam pembelajaran membaca dan menulis permulaan. Metode SAS merupakan metode pembelajaran yang digunakan untuk mengupas dan merangkai kata dengan cara melihat struktur penuh, lalu menganalisa dan mengetahui satu per satu unsur bacaan dari suatu kata atau kalimat (Emgusnadi, 2018).

Prinsip-prinsip metode SAS disusun berdasarkan landasan psikologis, landasan
Sebagai wahana dan fasilitas untuk meningkatkan kemampuan membaca siswa. peneliti akan melakukan penelitian tindakan kelas (PTK) dengan menerapkan metode SAS (Struktural Analitik Sintetik). Struktural analitik sintetik atau yang biasa disingkat dengan SAS merupakan salah satu metode yang dapat digunakan dalam pembelajaran membaca dan menulis permulaan. Prinsip-prinsip metode SAS disusun berdasarkan landasan psikologis, landasan pedagogis dan landasan ilmu bahasa (linguistik) (Emgusnadi, 2018). Oleh karena itu, dengan menerapkan metode SAS (Struktural Analitik Sintetik) diharapkan dapat meningkatkan keterampilan membaca siswa di SD Negeri 016 Marsawa Kecamatan Sentajo Raya.

pedagogis dan landasan ilmu bahasa (linguistik). Dari landasan inilah yang menjadi sumber langkah-langkah metode SAS yaitu, diawali dengan menyajikan satu keseluruhan atau struktur, menganalisis bagian-bagiannya, kemudian mensintesiskan bagian-bagian itu menjadi keseluruhan yang utuh (Kurniaman, 2017).

Langkah-langkah metode pembelajaran SAS terdiri dari lima fase. Adapun fase-fase tersebut dapat dilihat sebagai berikut:

Tabel 1. Langkah-langkah Metode SAS (Struktural Analitik Sintetik)

\begin{tabular}{|c|c|c|}
\hline No & Fase & Prilaku Guru \\
\hline 1. & $\begin{array}{l}\text { Melakukan apersepsi dan } \\
\text { motivasi kepada siswa dalam } \\
\text { pembelajaran }\end{array}$ & $\begin{array}{l}\text { Guru membimbing siswa mengamati sebuah gambar yang ada } \\
\text { dipapan tulis dan memberikan beberapa pertanyaan kepada } \\
\text { siswa. }\end{array}$ \\
\hline 2. & $\begin{array}{l}\text { Membaca kalimat sederhana } \\
\text { berdasarkan gambar dan kartu } \\
\text { kalimat. }\end{array}$ & $\begin{array}{l}\text { Guru memberikan kesempatan kepada siswa untuk membaca } \\
\text { kalimat sederhana dengan membaca kalimat secara } \\
\text { struktural. Caranya adalah menghilangkan gambar sehingga } \\
\text { tinggallah kartu-kartu kalimat yang dibaca oleh siswa. }\end{array}$ \\
\hline 3. & $\begin{array}{l}\text { Melakukan analisis terhadap } \\
\text { struktur kalimat. }\end{array}$ & $\begin{array}{l}\text { Guru membimbing siswa melakukan analisis terhadap struktur } \\
\text { dengan cara memisah-misahkannya menjadi kata, kata } \\
\text { menjadi suku kata, dan suku kata menjadi huruf. }\end{array}$ \\
\hline 4. & $\begin{array}{l}\text { Melakukan } \\
\text { (menggabungan }\end{array}$ & $\begin{array}{l}\text { Guru membimbing siswa melakukan proses sintesis dengan } \\
\text { cara menggabungkan kembali setiap unsur tersebut menjadi }\end{array}$ \\
\hline & $\begin{array}{l}\text { struktur lengkap } \\
\text { seperti semula) }\end{array}$ & \\
\hline 5. & Membuat kesimpulan & Guru membimbing siswa dalam membuat kesimpulan. \\
\hline
\end{tabular}


Ada beberapa keunggulan dalam menerapkan metode SAS, adapun keunggulan dalam menerapkan metode SAS dapat dilihat sebgai berikut: 1) metode ini dapat sebagai landasan berpikir analisis siswa di sekolah dasar; 2) dengan langkah-langkah yang diatur dengan baik membuat siswa lebih mudah mengikuti prosedur membaca dan akan dapat membaca dengan cepat; 3) dapat membantu siswa menjadi lebih menguasai bacaan dengan lancar. Sedangkan kekurangan metode SAS, yaitu: 1) hanya cocok

\section{METODE PENELITIAN}

Penelitian ini dilakukan di SD Negeri 016 Marsawa Kecamatan Sentajo Raya. Subjek Penelitian ini adalah Siswa kelas II SD Negeri 016 Marsawa dengan Jumlah 28 siswa, terdiri dari 16 siswa laki-laki dan 12 siswa perempuan.

Desain penelitian yang digunakan dalam penelitian ini menggunakan penelitian tindakan kelas (PTK). PTK adalah salah satu bentuk penelitian yang bersifat reflektif dengan memberikan tindakan tertentu sehingga dapat memperbaiki serta meningkatkan proses pembelajaran di kelas (dalam Arni, 2018). PTK ini dilaksanakan dalam dua siklus, setiap siklus terdiri dari beberapa tahapan sepert : 1) perencanaan, 3) pelaksanaan, 4) pengamatan, 5) refleksi (Hasniwati, 2019).

Adapun sumber data yang akan dimanfaatkan dalam penelitian ini antara lain : Informasi data dari nara sumber yang terdiri dari siswa kelas I, Ulangan Harian, Hasil pengamatan pelaksanaan pembelajaran dengan metode SAS. Teknik pengumpulan data ini dikumpulkan dengan menggunakan teknik observasi dan tes keterampilan membaca siswa. Observasi dalam kegiatan belajar mengajar dilakukan dengan tujuan untuk memperoleh gambaran, baik bersifat umum, maupun khusus yang berkenaan dengan aspek-aspek proses pendekatan yang dikembangkan. Aspek yang di observasi diantaranya ialah aktivitas siswa dalam belajar diterapkan pada anak yang sebelumnya tidak bersekolah di TK, karena metode ini sudah dikenalkan saat TK dan apabila diterapkan lagi kepada siswa yang sebelumnya besekolah di TK, maka akan membuat mereka bosan dalam mengikuti pelajaran; 2) metode SAS memrlukan persiapan sarana yang banyak sehingga dirasa sukar oleh para tenaga pendidik; dan 3) oleh karena agak sukar, maka para pengajar jarang menggunakan metode ini.

dan aktivitas guru dalam perencanaan dan pelaksanaan pembelajaran. Teknik tes dilakukan pada akhir pembelajaran dengan tujuan untuk mengetahui sejauh mana kemamapuan membaca siswa terhadap materi pembelajaran setelah dilakukan tindakan. Tes ini dilengkapi dengan format penilaian yang disesuaikan dengan kompetensi yang ingin diraih setelah pembelajaran.

Teknik analisis data yang digunakan ialah sebagai berikut:

\section{Analisis Data Aktivitas Guru dan Siswa}

Analisis data tentang aktivitas guru dan siswa didasarkan pada hasil yang diperoleh pada lembar pengamatan yang diambil pada saat proses pembelajaran berlangsung dengan melihat kesesuaian perencanaan dan pelaksanaan tindakan. Aktivitas guru dan siswa dalam pembelajaran dihitung dengan rumus sebagai berikut :

Nilai $=\frac{\text { Skor yang didapat }}{\text { Skor maksimal }} \times 100 \%$
(Mulyasa dalam Indot, 2018)

Setelah didapatkan hasil dari analisis aktivitas guru dan siswa dilakukan pengategorian hasil dari aktivitas guru dan siswa. adapun kategori aktivitas guru dan siswa dapat dilihat pada tabel berikut ini : 
Tabel 2. Kategori Aktivitas Guru dan Siswa

\begin{tabular}{cc}
\hline Interval & Kategori \\
\hline $90-100$ & Sangat Baik \\
\hline $70-89$ & Baik \\
\hline $50-69$ & Cukup \\
\hline $30-49$ & Kurang \\
\hline
\end{tabular}

\section{Analisis Hasil Belajar Membaca siswa.}

Analisis data tentang peningkatan hasil belajar keterampilan membaca siswa. Kemudian dianalisis menggunakan analisis persentase. Ketuntasan belajar telah tercapai oleh siswa apa bila hasil tes adalah 70 atau lebih. Data aktivitas belajar siswa dihitung dengan menggunakan rumus deskriptif persentase sebagai berikut:
Keterampilan : $\frac{n}{N}$ x $100 \%$

Keterangan :

Keterampilan membaca

$n \quad=$ Jumlah skor yang diperoleh dari data

$N \quad=$ Jumlah skor maksimal

Setelah didapat hasil belajar keterampilan membaca siswa, dilakukan pengkategorian hasil penelitian. Adapun kategori dari hasil penelitian dalam penelitian ini adalah sebagai berikut:

Tabel 3. Kategori Hasil Belajar Keterampilan Membaca Siswa

\begin{tabular}{cc}
\hline Interval & Kategori \\
\hline $80-100$ & Sangat Trampil \\
\hline $70-79$ & Trampil \\
\hline $60-69$ & Cukup \\
\hline $45-59$ & Kurang \\
\hline
\end{tabular}

\section{Analisis Keterampilan Membaca Siswa}

Tes dalam penelitian ini dilakukan untuk mengetahui kemampuan awal dan kemampuan akhir siswa dalam membaca. Kriteria penilaian berdasarkan aspek:

a. Kewajaran lafal.

b. Kewajaran intonasi.

c. Kelancaran. d. Kejelasan suara.

Pedoman penilaian membaca ini terdiri atas empat aspek yang kemudian dari masingmasing aspek diberi skor yang disesuaikan dengan tingkat kesulitan dari masing-masing aspek. Adapun rubrik penilaian keterampilan membaca siswa dapat dilahat pada tabel dibawah ini:

Tabel 4. Rubrik Penilaian Keterampilan Membaca Siswa

\begin{tabular}{|c|c|c|c|}
\hline No. & Aspek Penilaian & Unsur yang dinilai & Skor \\
\hline & & a. Siswa membaca dengan lafal yang benar & 3 \\
\hline \multirow[t]{2}{*}{1.} & Kewajaran lafal & b. Siswa membaca dengan lafal yang kurang benar & 2 \\
\hline & & c. Siswa membaca dengan lafal yang tidak benar & 1 \\
\hline \multirow[t]{4}{*}{2.} & Kewajaran intonasi & a. Siswa membaca dengan intonasi yang benar & 3 \\
\hline & & b. Siswa membaca dengan intonasi yang kurang benar & 2 \\
\hline & & c. Siswa membaca dengan intonasi yang tidak benar & 1 \\
\hline & & a. Siswa lancar dalam membaca & 3 \\
\hline \multirow[t]{3}{*}{3.} & Kelancaran & a. Siswa kurang lancar dalam membaca & 2 \\
\hline & & b. Siswa tidak lancar dalam membaca & 1 \\
\hline & & c. Kejelasan suara baik & 3 \\
\hline \multirow[t]{3}{*}{4.} & Kejelasan suara & b. Kejelasan suara cukup baik & 2 \\
\hline & & c. Kejelasan suara kurang baik & 1 \\
\hline & Jumlah skor & & 100 \\
\hline
\end{tabular}


Untuk mengetahui nilai rata-rata keterampilan membaca maka dapat dilakukan dengan cara membandingkan jumlah nilai seluruh siswa dengan jumlah seluruh siswa dengan rumus:

$\mathrm{X}=\frac{\sum x i}{\mathrm{n}} \mathrm{x} 100($ dalam Ridwan, 2010)

\section{HASIL DAN PEMBAHASAN}

Penelitian ini memberikan gambaran kontribusi metode SAS terhadap peningkatan kemampuan membaca siswa di kelas II SD Negeri 016 Marsawa. Pelaksanaan pembelajaran dengan menggunakan metode SAS bermula pada guru bercerita atau bertanya jawab dengan siswa disertai gambar yang dipajang di papan tulis untuk mengarahkan pembelajaran yang lebih konkrit. Siswa membaca beberapa kalimat yang ada di papan tulis dengan disertai gambar untuk mengembangkan kalimat berdasarkan gambar. Setelah siswa memahami suatu kalimat guru meminta kepada siswa untuk menganalisis kalimat menjadi suku kata, mensintesiskan
Keterangan :

$\bar{X}=$ Mean /rata-rata keterampilan membaca seluruh siswa

$\sum \mathrm{Xi}=$ Jumlah tiap data/ jumlah nilai seluruh siswa

$N=$ Jumlah data /jumlah seluruh siswa

kembali menjadi kalimat dan mengubah kalimat menjadi huruf.

Peningkatan hasil penelitian dapat kita lihat pada analisis pembelajaran berupa data peningkatan aktivitas guru, aktivitas siswa hasil belajar siswa dan hasil keterampilan membaca siswa. adapun hasil analisis data tersebut dapat dilihat sebagai berikut:

\section{Aktivitas Guru}

Aktivitas guru dari pertemuan pertama sampai pertemuan keempat, secara umum sudah sangat baik. Hal ini dapat dilihat pada tabel dibawah ini :

Tabel 5. Peningkatan Rata-rata Aktivitas Guru Siklus I dan II

\begin{tabular}{ccccc}
\hline Siklus & Pertemuan & Jumlah Skor & Persentase & Kategori \\
\hline I & 1 & 15 & $62.5 \%$ & Cukup \\
& 2 & 17 & $70.8 \%$ & Baik \\
II & 3 & 21 & $87.5 \%$ & Baik \\
& 4 & 23 & $95.8 \%$ & Sangat baik \\
\hline
\end{tabular}

Berdasarkan analisis tabel peningkatan aktivitas guru di atas dapat dilihat terjadi peningkatan aktivitas guru pada siklus I dan II dengan menerapkan metode SAS. Pada pertemuan pertama siklus I aktivitas guru memperoleh skor sebesar 15 dengan persentase $62.5 \%$ dengan kategori cukup. Sedangkan pada pertemuan kedua siklus I aktivitas guru memperoleh skor 15 dengan persentase sebesar $70.8 \%$ dengan kategori baik. pada siklus I ini, walaupun hasil penelitian meningkat akan tetapi masih terlihat guru kurang tepat dalam menyampaikan materi sehingga siswa kurang bisa menerima materi pembelajaran dengan baik dan guru menjelaskan materi seperti membaca buku sehingga membuat para siswa merasa jenuh dengan kegiatan pembelajaran tersebut dan tidak sedikit siswa yang ribut di dalam kelas.

Siklus II, pertemuan pertama aktivitas guru memperoleh skor sebesar 21 dengan persentase sebesar $87.5 \%$ dengan kategori baik. Sedangkan pada pertemuan kedua siklus II aktivitas guru memperoleh skor sebesar 23 dengan persentase sebesar $95.8 \%$ dengan kategori sangat baik. Pada siklus II ini, terlihat guru telah memahami tahapan-tahapan dalam menyampaikan materi dengan menggunakan metode SAS. Sehingga tidak terlihat lagi siswa yang meribut dan merasa bosan di dalam proses pembelajaran. dari hasil ini membuktikan dengan menerapkan model SAS dapat meningkatkan aktivitas guru didalam proses pembelajaran. 


\section{Aktivitas Siswa}

Samahalnya dengan aktivitas guru, aktivitas siswa selama penelitian menunjukan perubahan yang sangat baik. Hal ini dibuktikan dengan meningkatnya hasil aktivitas siswa setiap pertemuan. Adapun hasil penilaian aktivitas siswa dapat dilihat pada tabel berikut ini:

Tabel 6. Peningkatan Rata-rata Aktivitas Siswa Siklus I dan II

\begin{tabular}{ccccc}
\hline Siklus & Pertemuan & Jumlah Skor & Persentase & Kategori \\
\hline I & 1 & 14 & $58.3 \%$ & Cukup \\
& 2 & 16 & $66.6 \%$ & Cukup \\
II & 3 & 20 & $83.3 \%$ & Baik \\
& 4 & 22 & $91.6 \%$ & Sangat baik \\
\hline
\end{tabular}

Berdasarkan analisis tabel peningkatan aktivitas siswa di atas dapat dilihat terjadi peningkatan aktivitas siswa pada setiap siklusnya. Hal ini terlihat pada pertemuan pertama siklus I aktivitas siswa memperoleh skor sebesar 14 dengan persentase $58.3 \%$ dengan kategori cukup. Sedangkan pada pertemuan kedua siklus I aktivitas siswa memperoleh skor aktivitas sebesar 16 dengan persentase sebesar $66.6 \%$ dengan kategori cukup. Pada siklus I ini, masih terlihat siswa meribut di dalam kelas. Hal ini disebabkan siswa belum terbiasa dengan penerapan metode SAS, namun pada pertemuan kedua, aktivitas siswa sudah lebih baik dari pertemuan sebelumnya, namun antusias siswa dalam belajar masih perlu ditingatkan lagi.

Siklus II, pertemuan pertama aktivitas guru memperoleh skor sebesar 20 dengan persentase sebesar $83.3 \%$ dengan kategori baik. Sedangkan pada pertemuan kedua siklus II aktivitas guru memperoleh skor sebesar 22 dengan persentase sebesar $91.6 \%$ dengan kategori sangat baik. Pada siklus II ini, terlihat siswa telah terbiasa dan telah memahami tahapantahapan dalam pembelajaran SAS.

\section{Hasil Belajar Siswa dengan Menggunakan Metode SAS}

Kriteria ketuntasan minimal (KKM) yang ditetapkan oleh SD Negeri 016 Marsawa pada mata pelajaran bahasa Indonesia adalah 70 . Adapun hasil analisis ketuntasan belajar siswa dengan menggunakan metode SAS pada ulangan harian siklus I dan ulangan harian siklus II dapat dilihat tabel di bawah ini :

Tabel 7. Rekapitulasi Hasil Belajar Siswa Siklus 1 dan Siklus II dengan Menggunakan Metode SAS

\begin{tabular}{|c|c|c|c|c|c|c|c|c|}
\hline \multirow{2}{*}{ No } & \multirow{2}{*}{ Kriteria } & \multirow{2}{*}{$\begin{array}{c}\text { Jumlah } \\
\text { Siswa }\end{array}$} & \multicolumn{2}{|c|}{ Data Awal } & \multicolumn{2}{|c|}{ Siklus I } & \multicolumn{2}{|c|}{ Siklus II } \\
\hline & & & Jumlah & $(\%)$ & Jumlah & $(\%)$ & Jumlah & $(\%)$ \\
\hline 1 & $\begin{array}{c}\text { Siswa yang } \\
\text { tuntas }\end{array}$ & 28 & 13 & $46.4 \%$ & 21 & $75 \%$ & 25 & $89.2 \%$ \\
\hline 2 & $\begin{array}{l}\text { Siswa yang } \\
\text { tidak tuntas }\end{array}$ & 28 & 15 & $53.6 \%$ & 7 & $25 \%$ & 3 & $10.8 \%$ \\
\hline \multicolumn{3}{|c|}{ Jumlah } & 28 & $100 \%$ & 28 & $100 \%$ & 28 & $100 \%$ \\
\hline \multicolumn{3}{|c|}{ Ketuntasan Klasikal } & \multicolumn{2}{|c|}{ Tidak Tuntas } & \multicolumn{2}{|c|}{ Tuntas } & \multicolumn{2}{|c|}{ Tuntas } \\
\hline
\end{tabular}

Dari analisis data hasil belajar siswa dengan menerapkan model SAS di atas terjadi peningkatan. dilihat pada skor dasar, siswa yang tuntas sebanyak 13 dengan persentase $46.4 \%$ sedangkan siswa yang tidak tuntas sebanyak 15 dengan persentase $53.6 \%$ kategori tidak tuntas. Pada siklus I, siswa yang tuntas meningkat menjadi 21 dengan persentase $75 \%$, sedangkan 
siswa yang tidak tuntas sebanyak 7 orang dengan persentase 25\% dengan kategori tuntas. Pada siklus II, siswa yang tuntas kembali meningkat menjadi 25 dengan persentase $89.2 \%$, sedangkan yang tidak tuntas berkurang menjadi 3 orang dengan persentase $10.8 \%$ dengan kategori tuntas. Peningkatan hasil belajar siswa setiap siklusnya terjadi karena siswa telah memahami langkah langkah dalam pembelajaran SAS.

\section{Hasil Keterampilan Membaca Siswa}

Untuk peningkatan hasil keterampilan membaca siswa kelas II SD Negeri 016 Marsawa dapat dilihat pada tabel berikut:

Tabel 8. Peningkatan Rata-rata Keterampilan Membaca Siswa

\begin{tabular}{cccc}
\hline $\begin{array}{c}\text { Hasil Keterampilan } \\
\text { Membaca Siswa }\end{array}$ & Rata -Rata & $\begin{array}{c}\text { Peningkatan Membaca } \\
\text { SD - UH I }\end{array}$ & $\begin{array}{c}\text { Keterampilan Siswa SD - } \\
\text { UH II }\end{array}$ \\
\hline Skor Dasar & 60,07 & & \\
UH Siklus I & 72,80 & $(12.73 \%)$ & $(14.45 \%)$ \\
UH Siklus II & 87,25 & & \\
\hline
\end{tabular}

Berdasarkan analisis peningkatan ratarata keterampilan membaca siswa pada tabel diatas, dapat disimpulkan bahwa terjadi peningkatan dari skor dasar ke ulangan harian pada siklus I, dan ulangan harian siklus I ke ulangan harian pada siklus II. Terlihat bahwa pada skor dasar dengan rata-rata 60,07 kemudian mengalami peningkatan yaitu dengan jumlah ratarata 72.80 pada siklus I. Pada siklus II terjadi lagi

\section{SIMPULAN DAN REKOMENDASI}

Berdasarkan hasil penelitian di atas maka dapat peneliti simpulkan bahwa penerapan metode SAS dapat meningkatkan keterampilan membaca siswa kelas rendah di sekolah dasar. Adapun hasil peningkatan penelitiannya dapat dilihat sebagai berikut:

1. Aktivitas Guru; pada pertemuan pertama siklus I aktivitas guru memperoleh skor sebesar 15 dengan persentase $62.5 \%$ dengan kategori cukup. Sedangkan pada pertemuan kedua siklus I aktivitas guru memperoleh skor 15 dengan persentase sebesar $70.8 \%$ dengan kategori baik. Siklus II, pertemuan pertama aktivitas guru memperoleh skor sebesar 21 dengan persentase sebesar $87.5 \%$ dengan kategori baik. Sedangkan pada pertemuan kedua siklus II aktivitas guru memperoleh skor sebesar 23 dengan persentase sebesar $95.8 \%$ dengan kategori sangat baik.

2. Aktivitas Siswa; pada pertemuan pertama siklus I aktivitas siswa memperoleh skor sebesar 14 dengan persentase 58.3\% dengan kategori cukup. Sedangkan pada pertemuan peningkatan dengan rata-rata 87.25. peningkatan keterampilan membaca pada skor dasar ke siklus I sebesar $12.73 \%$ sedangkan peningkatan keterampilan membaca siswa pada siklus I ke siklus II sebesar $14.45 \%$. Peningkatan ini terjadi dikarenakan dengan penerapan metode SAS dan penggunaan media yang lebih menarik sehingga siswa dapat lebih fokus dalam pembelajaran.

kedua siklus I aktivitas siswa memperoleh skor aktivitas sebesar 16 dengan persentase sebesar $66.6 \%$ dengan kategori cukup. Siklus II, pertemuan pertama aktivitas guru memperoleh skor sebesar 20 dengan persentase sebesar 83.3\% dengan kategori baik. Sedangkan pada pertemuan kedua siklus II aktivitas guru memperoleh skor sebesar 22 dengan persentase sebesar $91.6 \%$ dengan kategori sangat baik.

3. Hasil Belajar Siswa; pada skor dasar, siswa yang tuntas sebanyak 13 dengan persentase 46.4\% sedangkan siswa yang tidak tuntas sebanyak 15 dengan persentase 53.6\% dengan kategori tidak tuntas. Pada siklus I, siswa yang tuntas meningkat menjadi 21 dengan persentase $75 \%$, sedangkan siswa yang tidak tuntas sebanyak 7 orang dengan persentase $25 \%$ dengan kategori tuntas. Pada siklus II, siswa yang tuntas kembali meningkat menjadi 25 dengan persentase $89.2 \%$, sedangkan yang tidak tuntas berkurang menjadi 3 orang dengan persentase $10.8 \%$ kategori tuntas. 
4. Hasil Keterampilan Membaca Siswa; pada skor dasar dengan rata-rata 60,07 kemudian mengalami peningkatan yaitu dengan jumlah rata-rata 72.80 pada siklus I. Pada siklus II terjadi lagi peningkatan dengan rata-rata 87.25. peningkatan keterampilan membaca pada skor dasar ke siklus I sebesar $12.73 \%$ sedangkan peningkatan keterampilan membaca siswa pada siklus I ke siklus II sebesar $14.45 \%$.

Berdasarkan simpulan di atas, peneliti menyampaikan beberapa rekomendasi yaitu

\section{DAFTAR PUSTAKA}

Abidin, Y. (2012). Pembelajaran Bahasa Berbasis Pendidikan Karakter. Bandung: Refika Aditama.

Ahmad Susanto. (2011). Perkembangan Anak Usia Dini Pengantar dalam Berbagai Aspeknya. Jakarta: Kencana Perdana Media Group.

Arni. (2018). Meningkatkan Hasil Belajar Matematika Siswa Kelas III Menggunakan Model Pembelajaran Kooperatif Tipe Think Pair Share (TPS) Di SD Negeri 018 Rantau Sialang Kecamatan Kuantan Mudik. Jurnal PAJAR (Pendidikan dan Pengajaran), 2 (5), 737-743.

Emgusnadi. (2018). Metode Pembelajaran SAS untuk Meningkatkan Keterampilan Membaca Siswa Kelas I SD Negeri 021 Sitorajo Kari Kecamatan Kuantan Tengah Kabupaten Kuantan Singingi. Jurnal PAJAR (Pendidikan dan Pengajaran), 2 (5), 659-665.

Hasniwati. (2019). Penerapan Model Pembelajaran Pictue and Picture untuk Meningkatkan Hasil Belajar IPA Siswa Kelas II A SD Negeri 004 Cendirejo Kecamatan Pasir Penyu Kabupaten Indragiri Hulu. Jurnal PAJAR (Pendidikan dan Pengajaran), 3(1), 189197.

Indot. (2018). Meningkatkan Kemampuan Membaca dan Menulis Siswa Kelas I dengan Menggunakan Media Flash Card SD Negeri 006 Sungai Buluh Kecamtan Singingi Hilir Kabupaten Kuantan sebagai berikut: 1) guru perlu memberikan latihan membaca yang lebih variatif dan perlu memberikan PR membaca lebih sering; 2) guru perlu memberikan penghargaan baik bentuk pujian maupun penilaian terhadap kerja siswa; 3) siswa yang belum bisa membaca lancar diberikan PR dalam membaca; 4) kepala sekolah perlu mendukung pembelajaran Bahasa Indonesia dengan inovasi baru dalam peningkatan keterampilan membaca siswa dengan cara lebih meningkatkan lagi minat baca siswa.

Singingi. Jurnal PAJAR (Pendidikan dan Pengajaran), 2(5), 667-673.

Kurniaman, O ., \& Noviana, E. (2016). Metode Membaca SAS (Struktural Analitik Sintetik) dalam Meningkatkan Keterampilan Membaca Permulaan di Kelas I SDN 79 Pekanbaru. Primary: Jurnal Pendidikan Guru Sekolah Dasar, 5(2), 149-157.

Mariayana. (2016). Penerapan Teknik Membaca Sekilas untuk Menentukan Gagasan Pokok Siswa Kelas IV SDN 015 Pagaran Tapah Darussalam. Primary: Jurnal Pendidikan Guru Sekolah Dasar, 5(3), 72-78.

Ridwan. (2010). Skala Pengukuran VariabelVariabel Penelitian. Bandung: Alfabeta.

Simanjuta, D. (2017). Penerapan Strategi Directed Reading Activity (DRA) untuk Meningatkan Kemampuan Siswa dalam Membaca Pemahaman Kelas V SDN 003 Pagaran Tapah Darussalam Kabupaten Rokan Hulu. Primary: Jurnal Pendidikan Guru Sekolah Dasar, 6(1), 47-57.

Tarigan, H. G. (2008). Membaca sebagai Suatu Keterampilan Berbahasa. Bandung: Angkasa.

Wigati, S. (2015). Meningkatkan Kemampuan Membaca Permulaan Menggunakan Media Tabung Kata Kelompok B Tk Dharma Wanita Wonokromo Desa Wonokromo Kecamatan Gondang Kabupaten Tulungagung Tahun Ajaran 2014-2015. Kediri: Universitas Kediri. 